\title{
A RHEUMATOID-LIKE FACTOR IN PATIENTS WITH TISSUE DAMAGE
}

\author{
BY \\ W. M. RUSSELL AND M. S. R. HUTT* \\ Louis Jenner Laboratory, St. Thomas's Hospital, London
}

The demonstration of a specific factor in the serum of patients with rheumatoid arthritis using sheep red cells sensitized with homologous rabbit antibody (Rose, Ragan, Pearce, and Lipman, 1948) has been followed by a variety of new techniques for detecting this factor. Substitution of sensitized red cells by polystyrene latex (Singer and Plotz, 1956) or bentonite particles (Bozicevich, Bunim, Freund, and Ward, 1958) coated with human or bovine gamma globulin gives satisfactory results, and slidescreening tests using sensitized latex particles are now in general use (Greenbury, 1957). Agreement between these various tests is usually of the order of 90 per cent. in sera submitted for the diagnosis of rheumatoid arthritis, and positive results are obtained in from 80 to 90 per cent. of cases (Greenbury, 1957). Occasional false positive reactions are reported with all the tests described, but these are usually confined in most reports to so-called "collagen diseases". Dresner and Trombly (1959), however, have reported false positive results with the standard sensitized latex test in a wider variety of disease processes. They have also shown that increasing the sensitivity by using the euglobulin fraction of the serum (Ziff, Brown, Lospalluto, Badin, and McEwen, 1956) resulted in a marked loss of specificity.

This paper describes some observations on false positive results obtained while investigating the value of a slide test using bentonite particles sensitized with bovine gamma globulin.

\section{Clinical Material}

The sera investigated came from a number of sources. All were stored at $-20^{\circ} \mathrm{C}$. before testing.

(1) Sera from 200 patients submitted for routine tests for the rheumatoid factor. The majority of these patients were suspected of having rheumatoid arthritis;

* Present address: Dept. of Pathology, Makerere University College, Kampala, Uganda. the remainder had other types of arthritis or "collagen disease".

(2) Sera from hospital patients whose blood was sent for grouping. This group was selective in that it consisted only of patients in whom transfusion was a possibility, and therefore included a high percentage of cases of carcinoma and trauma.

(3) Sera selected from other hospital patients.

\section{Laboratory Materials and Methods}

(1) Bentonite Slide Test (B.T.) (after Bozicevich and others, 1958).

(a) Preparation of Bentonite. -1 g. bentonite is mixed in a blender with 11 . distilled water and allowed to stand in a measuring cylinder for 1 hour. The supernatant is then poured into two $500-\mathrm{ml}$. bottles and centrifuged at 1,300 r.p.m. in a M.S.E. magnum centrifuge for exactly 15 minutes. The supernatant is then poured into two further bottles and the process repeated at 1,600 r.p.m. The supernatant from this centrifuging is then discarded and the deposit with approximately $50 \mathrm{ml}$. residual supernatant is divided into five equal volumes and poured into five test tubes which are centrifuged until all the bentonite is sedimented. The supernatant is then discarded and the deposits stored at $4^{\circ} \mathrm{C}$.

(b) $0.5 \mathrm{~g}$. bovine Fraction II gamma globulin (Armour) is dissolved by shaking in $25 \mathrm{ml}$. veronal buffer of pH 8.6.

(c) Sensitization of Bentonite. $-5 \mathrm{ml}$. of the gamma globulin solution is added to the test tube prepared as in (a) and re-suspended. This is kept at room temperature for half an hour, and is then washed twice with distilled water and stored as a sediment in the test tube at $4^{\circ} \mathrm{C}$. One drop of this sensitized bentonite is diluted before use with 40 drops of Sorenson's phosphate buffer at $\mathrm{pH} \mathrm{7 \cdot 5.}$

(d) Each serum to be tested is diluted 1 in 20 with normal saline $(0.85$ per cent.). One drop of each diluted serum is placed on a glass tile and one drop of sensitized bentonite is added and mixed. Agglutination 
is shown by the appearances of particles in the smooth bentonite suspension. In each batch of sera tested, positive and negative controls are included. Readings are usually made at about 4 minutes, but this is determined partly by the behaviour of the negative controls. In most batches of prepared bentonite granularity is usually evident in all the sera after 10 minutes.

(2) Sheep Cell Agglutination Test or Waaler-Rose Test (S.C.A.T.).-The method used was that of Greenbury (1957), except that serum saline was not used to make the serum dilutions. In this series we have considered the test to be positive at a serum dilution of 1 in 32 .

(3) Hyland "R.A." Latex Test (L.T.).-This is a commercially produced latex/Fraction II gamma globulin reagent. A drop of the reagent is mixed on a slide with a 1 in 20 dilution of patient's serum in glycine buffer and the result is read at 2 minutes.

(4) Tube Latex Test.-This test was performed by the method of Payne (1961). In this series we have considered the test to be positive at a serum dilution of 1 in 40.

(5) C-Reactive Protein (Hyland) (C.R.P.).- This test was performed according to the manufacturers' instructions. The reagent is an antiserum against $\mathrm{C}$-reactive protein absorbed on to latex particles.

\section{Results}

Comparison between the S.C.A.T., L.T., and B.T. in Sera submitted for Routine S.C.A.T.

There was complete agreement between all three tests in 80 per cent. of the 200 sera tested (see Table I). $7 \cdot 5$ per cent. of the sera were positive with the B.T. alone, and another 7 per cent. were positive with the B.T. and L.T. but negative with the S.C.A.T. Analysis of this 14.5 per cent. showed that these sera were obtained from patients who did not have classical rheumatoid arthritis; they

TABLE I

INCIDENCE OF POSITIVE REACTIONS IN 200 SERA SUBMITTED FOR S.C.A.T.

\begin{tabular}{c|c|c|c|c}
\hline S.C.A.T. & L.T. & B.T. & No. & Per cent. \\
\cline { 2 - 4 }+ & + & + & 49 & $24 \cdot 5$ \\
+ & \pm & \pm & 1 & $0 \cdot 5$ \\
+ & \pm & - & 6 & $3 \cdot 0$ \\
\pm & \pm & \pm & 0 & 0 \\
- & + & + & 112 & $56 \cdot 0$ \\
- & \pm & - & 3 & $7 \cdot 0^{*}$ \\
- & - & + & 15 & $7 \cdot 5$ \\
\hline
\end{tabular}

* These sera were from patients who did not have typical rheumatoid arthritis (see text). included patients with atypical arthritis, ankylosing spondylitis, and suspected "collagen diseases". Five of the sera with positive latex and bentonite tests with negative results on the standard S.C.A.T. were re-tested, using red cells sensitized to the point of agglutination (Greenbury, 1960); three remained $\frac{7}{\sigma}$ negative and two became just positive. The tube latex test in this series agreed with the S.C.A.T. in 90 per cent. of the sera tested.

\section{Comparison between the L.T. and B.T. in Sera from $\vec{\circ}$} 74 Non-Rheumatoid Cases

The results in Table I suggested that the S.C.A.T. was the most specific test for rheumatoid arthritis and that the B.T. was less specific than the L.T. In a series of 74 sera submitted for blood grouping. from non-rheumatoid cases, 16 per cent. of the sera $\omega$ were positive with the B.T. only, 4 per cent. with L.T. only, and 12 per cent. with both (Table II).

$$
\text { TABLE II }
$$

INCIDENCE OF POSITIVE REACTIONS WITH THE L.T. AND B.T. IN 74 SERA SUBMITTED FOR BLOOD GROUPING

\begin{tabular}{c|c|c|cc}
\hline L.T. & B.T. & No. & \multicolumn{2}{|c}{ Per cent. } \\
\hline+ & + & 9 & 12 & $\frac{0}{0}$ \\
- & - & 50 & 68 & $\frac{1}{2}$ \\
+ & + & 12 & 16 & $\frac{0}{2}$ \\
\hline
\end{tabular}

These results confirm that the B.T. is much more $\stackrel{2}{\circ}$ liable to give false positive results than the L.T. $\stackrel{\mathbb{Q}}{\varrho}$ One serum from a patient with carcinomatosis gave $\overrightarrow{\overrightarrow{0}}$ a strong positive with the B.T. This serum was 3 then titred, using the B.T., the L.T., and the tube latex test. The respective titres were 1 in 80 , 1 in 20 , and 1 in 10.

Analysis of False Positive B.T.s in Non-Rheumatoid Sera

315 sera taken at random from blood grouping were tested by the B.T. (Table III). Analysis of the 음 59 strongly positive tests showed that 27 of the sera

TABLE III

INCIDENCE OF POSITIVE REACTIONS WITH THE B.T. IN N 315 SERA SUBMITTED FOR BLOOD GROUPING

\begin{tabular}{|c|c|c|c|c|}
\hline Result & & & No. & Per cent. \\
\hline $\begin{array}{l}\text { Negative } \\
\text { Strongly positive } \\
\text { Weak positive }\end{array}$ & $\begin{array}{l}\ldots \\
\cdots \\
\cdots\end{array}$ & $\begin{array}{c}\ldots \\
\cdots \\
\ldots\end{array}$ & $\begin{array}{r}226 \\
59 \\
30\end{array}$ & $\begin{array}{r}72 \cdot 0 \\
19 \cdot 5 \\
8 \cdot 5\end{array}$ \\
\hline
\end{tabular}


were from patients with carcinoma or other malignant tumours, eighteen from patients with acute or chronic inflammatory processes including liver disease, four from patients with recent fractures, six from patients who had had recent operations, and four from subjects in whom the diagnosis was not established. The thirty sera with weakly positive tests came from patients with similar disease processes.

\section{Investigations of the Relationship between Tissue Damage and False Positive B.T.s}

The results with the slide B.T. shown in Table III suggested that tissue damage was the common factor giving rise to the false positive results. To test this theory, 82 sera from routine blood grouping were tested in comparison with the test for Creactive protein (Table IV). The results showed agreement in 78 per cent. of the sera tested, with 18.5 per cent. of the sera positive with both tests. 7 per cent. were positive only with the C.R.P. and 14.5 per cent. positive only with the B.T. All the sera which gave positive results were from patients who had tissue damage.

$$
\text { TABLE IV }
$$

INCIDENCE OF POSITIVE REACTIONS WITH THE C-REACTIVE PROTEIN TEST AND THE B.T. IN 82 SERA SUBMITTED FOR BLOOD GROUPING

\begin{tabular}{c|c|c|c}
\hline C.R.P. & B.T. & No. & Per cent. \\
\hline \pm & + & 15 & $18 \cdot 5$ \\
+ & \pm & 49 & $60 \cdot 0$ \\
- & + & 6 & $7 \cdot 0$ \\
\hline
\end{tabular}

To confirm the association of false positive results with tissue damage, we tested 33 sera submitted for transaminase (S.G.O.T.) estimations. 25 of these sera with S.G.O.T. levels of 40 units or less produced only three weak positive results with the B.T., but five of the eight sera with S.G.O.T. levels of over 40 units were positive; these five sera had S.G.O.T. levels over 55 units.

In one patient with a cardiac infarct, serial S.G.O.T.s and B.T.s were performed. The S.G.O.T. was raised on the first day and remained high during the next 4 days; the B.T. did not become positive until the fourth day when the erythrocyte sedimentation rate (E.S.R.) had also risen.

25 sera submitted for virus antibody investigations were tested by the B.T., and positive results were obtained in eleven of these sera. Eight sera with strong positive Wassermann reactions were also tested, and no positive results were obtained.
Dresner and Trombly (1959) have suggested that macroglobulins are responsible for the positive latex test and that diseases with hyperglobulinaemia may give a false positive result with the L.T. Therefore a number of sera sent to the laboratory for routine electrophoresis were tested with the B.T. Although several of the sera with a positive B.T. showed a raised $\alpha_{2}$ globulin, some showed no electrophoretic abnormality. Hypergammaglobulinaemia was not constantly associated with a positive B.T. The great majority of patients with positive bentonite tests had high E.S.R.s, but occasional positive results were obtained in patients in whom the E.S.R. was normal.

\section{Investigations into the Conditions affecting the Agglutination of Bentonite Particles}

Unsensitized bentonite was compared with bentonite sensitized with gamma globulin by preparing suspensions of comparable opacity in Sorensen's phosphate buffer at $\mathrm{pH} 7 \cdot 5$. The unsensitized bentonite was agglutinated by all normal and abnormal sera tested at the standard dilution of 1 in 20 in physiological saline. This agglutination factor was absorbed by unsensitized bentonite but not by sensitized bentonite. Unsensitized latex was also agglutinated by all normal sera.

There was no significant difference in the degree of agglutination of sensitized bentonite by rheumatoid sera if the washing process was omitted after sensitization. Bentonite sensitized with a human gamma globulin fraction (fraction G3, Lister Institute) gave results which were similar to the bovine gamma globulin.

Serum from a case of rheumatoid arthritis with a S.C.A.T. titre of 1 in 128 was diluted in 1 in 20 in physiological saline, and four $0.5 \mathrm{ml}$. aliquots of the diluted serum were absorbed with equal volumes of sensitized latex, sensitized bentonite, unsensitized latex, and unsensitized bentonite of standard dilution. The rheumatoid factor was completely absorbed in each instance.

Serum from a case of tissue damage which gave a strong positive slide bentonite test was absorbed with sensitized and unsensitized bentonite. In both instances the serum failed to react with sensitized bentonite after absorption.

Heating the sera to $56^{\circ} \mathrm{C}$. for 30 minutes did not abolish either type of reaction.

\section{Discussion}

The results shown in Table I suggest that the S.C.A.T. is most specific for rheumatoid arthritis, the L.T. is slightly less specific, and the B.T. least 
specific. Although false positive results may occur with the S.C.A.T., these are mainly confined to the so-called "collagen diseases", such as disseminated lupus erythematosus and systemic sclerosis (Kellgren and Ball, 1959). Singer and Plotz (1956) recorded positive results with the tube latex test in some patients with disseminated lupus erythematosus and also in cases of hyperglobulinaemia. Dresner and Trombly (1959), using a latex test, found false positives in patients with liver disease, virus infections, syphilis, and hyperglobulinaemia. They also showed that, if the euglobulin fraction of the serum was used (Ziff and others, 1956), the number of false positives was greatly increased. Bozicevich and others (1958), using a tube bentonite test, reported only three false positive results among 163 controls that included 41 patients with carcinoma of various organs. Holley, Hammack, and Douglas (1961) reported false positives with the tube latex test and tube bentonite test in patients with cirrhosis, sarcoidosis, and hyper- and macroglobulinaemic purpura of Waldenström.

In the series of 74 sera sent for blood grouping, the L.T. gave 16 per cent. of false positives and the B.T. 28 per cent. The majority of false positives with the L.T. were only weak reactions and we have found that by increasing the serum dilution to 1 in 32 the majority of these false positives were eliminated without significant loss of true positive reactions with rheumatoid sera. These results show that the slide B.T. is the least specific test for the rheumatoid factor. In the larger series of 315 sera sent for blood grouping, the slide bentonite test was again found to be positive in 28 per cent. Analysis of the cases in which the sera gave false positive results showed that they were nearly all obtained from patients with tumours, bacterial or virus infections, or recent trauma. Furthermore, it was found that the sera from patients with small superficial tumours such as early carcinoma of breast were negative, while those from large or disseminated tumours were positive. These results suggested that tissue damage or necrosis was the common factor. Clinical confirmation of this was obtained by demonstrating a reversal of a negative test to positive in one patient after a myocardial infarct, and in another after an extensive abdominal operation. One patient whose serum gave a strongly positive B.T. was shown on the laboratory diagnostic card to have iron deficiency anaemia; examination of the out-patient notes, however, revealed that she also had pain in the foot and that an $x$ ray revealed a fractured metatarsal! A comparison of the B.T. with other tests for tissue damage, C-reactive protein, S.G.O.T., and the E.S.R. showed that there was a close but not complete correlation with each of these tests. Hypergammaglobulinaemia was a rare finding in our patients with false positive results; some showed a raised $\alpha_{2}$ globulin but in others there was no electrophoretic abnormality. $\stackrel{0}{\rightarrow}$ It appears, therefore, that the false positive B.T.s fall into the group of non-specific "acute phase" 흠 phenomena associated with tissue injury. This $\frac{\bar{m}}{\frac{5}{\sigma}}$ includes the E.S.R., plasma viscosity, C-reactive $\stackrel{\mathbb{D}}{\square}$ protein, S.G.O.T., serum polysaccharides, and electrophoretic abnormalities (Bywaters and Scott, 1960).

Our experience with the S.C.A.T. in comparison with the L.T. and B.T. confirms that the tests are not detecting identical substances. This is shown by occasional gross discrepancies between the tests iv in individual patients, the false positive results with $\vec{\omega}$ the L.T. and B.T. in some patients with tissue is damage, and by the observation that the S.C.A.T. $ै$ factor can be absorbed completely with sensitized 은 sheep cells leaving the L.T. factor still active (Heller, Jacobson, Kolodny, and Kammerer, 1954; Tray- $\mathcal{P}$ ford, 1961, unpublished results). Sensitization of $\frac{\mathbb{O}}{O}$ bentonite or latex particles with gamma globulin, as described in our techniques, leads to increased suspension stability so that, unlike unsensitized particles, they are not agglutinable by normal seroß In the sensitized state, however, the particles ate agglutinated by factors present in the sera of patienta with rheumatoid arthritis, and some patients with tissue damage. Although these two factors are apparently different they are almost certainly both macroglobulins (Singer, 1961). Both these $\mathbb{D}$ factors are absorbed by sensitized and unsensitized bentonite. The differences between the L.T. and the B.T. are probably due to the physical conditions which govern the suspension stability of the sensitized particles. There is no evidence that the loss of specificity with the B.T. is due to the use of Bovine F.II gamma globulin as this was also used in the tube latex test.

The exact mode of action of the rheumatoid factor in causing agglutination of sensitized red

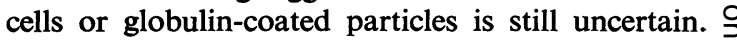
It has been suggested that the rheumatoid factor $D$ is a non-specific agglutination activating factor and that its action is analogous to that of bovine $N$ albumin on incomplete rhesus antibodies. Alternatively, the rheumatoid factor may act as an anti- $N$ body against globulin whose prosthetic groups have $N_{\omega}$ been exposed by attachment to an antigen or particle such as latex or bentonite (Glynn, Holborow, and Johnson, 1957).

The clinical circumstances, such as trauma, in which false positives are found with the B.T. make 
it difficult to conceive that the tissue damage factor is an antibody in the accepted sense of the word. However, detection of tissue damage by an immunological technique has been shown by Gajdusek (1957), using an auto-immune complement fixation test (A.I.C.F.) in which the antigens are saline extracts of normal tissue. Hackett, Beech, and Forbes (1960), who performed the A.I.C.F. in a wide variety of conditions, remarked that the diseases in which the A.I.C.F. was most commonly positive were similar to those in which false positives were obtained by the latex test for rheumatoid arthritis. They went on to suggest that such reactions all detected a similar factor in serum which was the presence of abnormal large-molecule globulin aggregates.

It is suggested that a more detailed study of the immunological abnormalities in tissue damage using a wider variety of serological techniques, such as that used in the survey published by Hijmans, Doniach, Roitt, and Holborow (1961), might increase our understanding both of the results of tissue damage and of its relation to auto-immune phenomena.

\section{Summary}

A slide-screening test for rheumatoid arthritis, using bentonite particles coated with bovine gamma globulin, is described. This test is less specific than a commercial latex-fixation slide test, although both give false positive reactions when compared with the sheep cell agglutination test. Clinical and laboratory investigations suggest that these false positive reactions are due to rheumatoid-like factors released after non-specific tissue damage. The mechanism of these reactions and their significance in relation to auto-immune phenomena are discussed.

Our thanks are due to Mr. G. Trayford for technical assistance, and to Dr. M. Ridley for helpful criticism and advice.

\section{REFERENCES}

Bozicevich, J., Bunim, J. J., Freund, J. and Ward, S. B. (1958). Proc. Soc. exp. Biol. (N.Y.), 97, 180.

Bywaters, E. G. L., and Scott, F. E. T. (1960). In "Recent Advances in Clinical Pathology", Ser. 3, ed. S. C. Dyke, p. 278. Churchill, London.

Dresner, E., and Trombly, P. (1959). New Engl. J. Med., 261, 981.

Gajdusek, D. C. (1957). Nature (Lond.), 179, 666.
Glynn, L. E., Holborow, E. J., and Johnson, G. D. (1957). Proc. roy. Soc. Med., 50, 469.

Greenbury, C. L. (1957). Ass. clin. Path. Broadsheet, No. 18. (1960). J. clin. Path., 13, 325.

Hackett, E., Beech, M., and Forbes, I. J. (1960). Brit. med. J., $2,17$.

Heller, G., Jacobson, A. S., Kolodny, M. H., and Kammerer, W. H. (1954). J. Immunol., 72, 66.

Hijmans, W., Doniach, D., Roitt, I. M., and Holborow, E. J. (1961). Brit. med. J., 2, 909.

Holley, H. L., Hammack, W. J., and Douglas, C. (1961). Amer, J. med. Sci., 242, 331.

Kellgren, J. H., and Ball, J. (1959). Brit. med. J., $1,523$.

Payne, R. B. (1961). J. clin. Path., 14, 309.

Rose, H. M., Ragan, C., Pearce, E., and Lipman, M. O. (1948). Proc. Soc. exp. Biol. (N.Y.), 68, 1.

Singer, J. M. (1961). Amer. J. Med., 31, 766.

and Plotz, C. M. (1956). Ibid., 21, 888.

Trayford, G. H. (1961). Personal communication.

Ziff, M., Brown, P., Lospalluto, J., Badin, J., and McEwen, C. (1956). Amer. J. Med., 20, 500.

Un facteur du type rhumatismal chez des malades avec des lésions tissulaires

\section{RÉSUMÉ}

On décrit un test microscopique pour l'arthrite rhumatismale usant des particules de bentonite enduites de gamma-globuline bovine. Ce test est moins spécifique que le procédé de fixation à l'aide d'un produit commercial contenant un réactif au latex, mais les deux méthodes peuvent donner de faux résultats positifs lorsqu'on les vérifie par la réaction d'agglutination des érythrocytes de mouton. Des recherches cliniques et de laboratoire indiquent que ces fausses positivités sont dues aux facteurs du type rhumatismal, libérés après l'occurrence de non-spécifiques lésions tissulaires. On discute le mécanisme de ces réactions et leur importance par rapport aux phénomènes d'auto-immunité.

\section{Un factor de carácter reumatoide en enfermos con lesiones tisulares \\ SUMARIO}

Se describe un test microscópico para artritis reumatoide usando particulas de bentonite recubiertas con gamma-globulina bovina. Este test es menos específico que el procedimiento de fijación en que se emplea un producto comercial conteniendo un reactivo con latex, pero ambos métodos pueden dar falsos resultados positivos al averiguarlos por la reacción de aglutinación de los eritrocitos de cordero. Investigaciones clínicas y de laboratorio sugieren que estas falsas positividades se deben a factores parecidos al factor reumatoide, liberados después de lesiones tisulares no específicas. Se discute el mecanismo de estas reacciones y su significación en relación con fenómenos de auto-inmunidad. 